\title{
Gastrointestinal stromal tumour of the duodenum in childhood: a rare case report

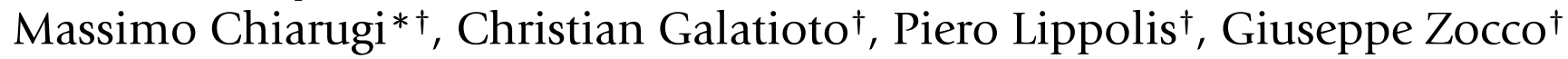 and Massimo Seccia ${ }^{\dagger}$
}

Address: Department of Surgery, University of Pisa, Pisa, Italy

Email: Massimo Chiarugi* - m.chiarugi@dc.med.unipi.it; Christian Galatioto - c.galatioto@mail.ao-pisa.toscana.it;

Piero Lippolis - p.lippolis@mail.ao-pisa.toscana.it; Giuseppe Zocco - g.zocco@dc.med.unipi.it; Massimo Seccia - m.seccia@dc.med.unipi.it

* Corresponding author †Equal contributors

Published: 9 May 2007

BMC Cancer 2007, 7:79 doi:10.1186/147/-2407-7-79
Received: 13 June 2006

Accepted: 9 May 2007

This article is available from: http://www.biomedcentral.com/I47/-2407/7/79

(c) 2007 Chiarugi et al; licensee BioMed Central Ltd.

This is an Open Access article distributed under the terms of the Creative Commons Attribution License (http://creativecommons.org/licenses/by/2.0), which permits unrestricted use, distribution, and reproduction in any medium, provided the original work is properly cited.

\begin{abstract}
Background: Gastrointestinal stromal tumours (GISTs) are uncommon primary mesenchymal tumours of the gastrointestinal tract mostly observed in the adults. Duodenal GISTs are relatively rare in adults and it should be regarded as exceptional in childhood. In young patients duodenal GISTs may be a source of potentially lethal haemorrhage and this adds diagnostic and therapeutic dilemmas to the concern about the long-term outcome.
\end{abstract}

Case presentation: A 14-year-old boy was referred to our hospital with severe anaemia due to recurrent episodes of upper gastrointestinal haemorrhage. Endoscopy, small bowel series, scintigraphy and video capsule endoscopy previously done elsewhere were negative. Shortly after the admission, the patient underwent emergency surgery for severe recurrence of the bleeding. At surgery, a $4 \mathrm{~cm}$ solid mass arising from the wall of the fourth portion of the duodenum was identified. The invasion and the erosion of the duodenal mucosa was confirmed by intra-operative pushed duodenoscopy. The mass was resected by a full-thickness duodenal wall excision with adequate grossly free margins. Immunohistochemical analysis of the specimen revealed to be positive for CDII7 (c-KIT protein) consistent with a diagnosis of GIST. The number of mitoses was $<5 / 50$ HPF. Mutational analysis for c-KIT/PDGFRA tyrosine kinase receptor genes resulted in a wildtype pattern. The patient had an uneventful course and he has remained disease-free during two years of follow-up.

Conclusion: Duodenal GISTs in children are very rare and may present with massive bleeding. Cure can be achieved by complete surgical resection, but even in the low-aggressive tumours the long-term outcome may be unpredictable.

\section{Background}

Gastrointestinal stromal tumours (GISTs) are uncommon mesenchymal tumours of the gastro-intestinal tract (GI) believed to originate from the interstitial cells of Cajal (ICC) [1]. Likewise ICC, the GIST cells carry the receptor tyrosine kinase (KIT). Immunohistochemically the specific marker for KIT (CD117) is used to distinguish GIST from others spindle-cell tumours of the GI. Although a GIST may arise anywhere in the GI, stomach and small bowel are the most elective sites [2]. It can be estimated 
that the frequency location of GISTs in the duodenum account approximately to 5\% [3-5]. GISTs are far more common in adults, and over the age of 40. A report focused on the epidemiology of GISTs and including 1,458 cases found no patient below the age of 20 [6]. Others large sample size retrospective studies confirm that GISTs are mostly observed in adults and are rare in children. Only $2.7 \%$ of GISTs of the stomach and $0.6 \%$ of GISTs of the small-bowel occur before the age of 21 years and the mean age of patients presenting with duodenal GISTs is over 50 [3-5]. Duodenal GISTs in children are extremely rare. We report a new clinical observation to enforce knowledge about GISTs of the duodenum in young patients.

\section{Case presentation}

A 14 year-old boy was referred to the emergency department for severe episodes of upper gastrointestinal bleeding, the first of whom dated back to one year. A few days before, the patient had been admitted elsewhere for melena, tachycardia, mild hypo-tension and severe anaemia (Hb7.5 g/dl). At that time, after blood volume replacement, the patient underwent upper and lower endoscopy studies, abdominal ultrasound (US) scan, pertecnate $99 \mathrm{~m}$ (Tc99m) scintigraphy and video-capsule enteroscopy, all of which resulted negative. The patient rebled severely shortly after his arrival at the emergency department and surgery was warranted. At laparotomy there was fresh blood into the jejunum and ileum but not into the stomach. Exposure of the duodenum by extended Kocher's manoeuvre and Treitz's ligament take-down, allowed the detection of a roundish solid mass, $4 \mathrm{~cm}$. in diameter, arising from the pancreatic border of the fourth portion of the duodenum. The mass, mostly esophytic, did not invade the pancreatic body (Figure 1).

Intra-operative pushed upper endoscopy was performed. At endoscopy, the tumour protruded into the lumen and centrally ulcerated the mucosa. (Figure 2) A mild ongoing haemorrhage from the erosion was seen.

The duodenal wall was carefully dissected free from the lower pancreatic border and from the superior mesenteric artery. Removal of the mass was then accomplished by a full-thickness excision of the anterior duodenal wall with adequate grossly free margins. The duodenal defect was over-sewn and covered by an omental patch.

Histopathologic report revealed the tumour was composed by epithelioid and spindle cells (Figure 3), with a mitotic activity $<5$ per 50 high power field (HPF). The tumour stained positive for CD117 (Figure 4), CD34 and smooth muscle actine and negative for $\mathrm{S} 100$ protein, $\mathrm{CK}$ pan, CD45-LCA, and melanosome, consistent with the diagnosis of GIST. Genomic DNA was isolated from par- affin-embedded tumor tissue. Molecular work-up based on polymerase chain amplification followed by direct sequence analysis of selected coding sequences of KIT (exons 9,11, and 13) and platelet-derived growth factor receptor $\alpha$ (PDGFR $\alpha$; exons 12,14 , and 18 ) yielded no evidence of mutation. As diagnosis of GIST was made, the patient was investigated to detect clinical features of type 1 neurofibromatosis and of Carney's triad (GIST associated with paraganglioma and pulmonary chondroma). Both syndromes were excluded. In addition, no other family members resulted affected by GIST. The course was uneventful and the patient has remained asymptomatic with no local or distant recurrence at the two years followup. No program of imatinib mesylate chemotherapy was undertaken.

\section{Conclusion}

Most GISTs arise in adults over 40 years of age [6]. In the pediatric age group, GISTs occur in the sporadic form and in some cases are associated with Carney's triad or type 1 neurofibromatosis. Rare cases of familial GISts which carry a KIT or PDGFRa germline mutation have been also described $[7,8]$. The duodenal localization of a GIST in children is however exceptional. Cypriano and Coll. [9] reported in 2004 a series of 7 pediatric patients affected by GIST: none of them originated from the duodenum. More recently, from a review of the English-language biomedical literature, Hayashi \& Coll.[10] found 25 children affected by GIST, none of them with a duodenal localization. Two further series of pediatric GISTs, each collecting five cases, failed to identify a duodenal localization $[11,12]$. So far, the only previously described pediatric patient with a duodenal GIST is by Towu and Coll. that reported in two papers the case of a 7-year-old boy: bleeding was the clinical presentation and the tumour was successfully resected $[13,14]$. Likewise in adults, duodenal GISTs in children may have an acute clinical onset, with bleeding as one of the most common complication. Endo-luminal bleeding is the expression of local invasion and erosion of the GI mucosa. For GISTs of the foregut, the identification of the source of bleeding may be easily performed by upper endoscopy whenever the tumor is located in the stomach or in the upper duodenum. On the other hand GISTs of the distal duodenum may remain undetected at endoscopy. Alternative diagnostic means for occult upper GI bleeding include duodenum series, US and computed tomography, video-capsule endoscopy, Tc99m scintigraphy and angiography. In the presented cases most of them resulted un-effective in making the diagnosis that was cleared only at surgery. Surgical removal of a duodenal GIST may be accomplished by several options, ranging from the minimal to outmost demolitive procedures. Local tumour excision [15], segmental duodenal resection [16-18] and pancreatoduodenectomy [19-21] have all been advocated, depending 


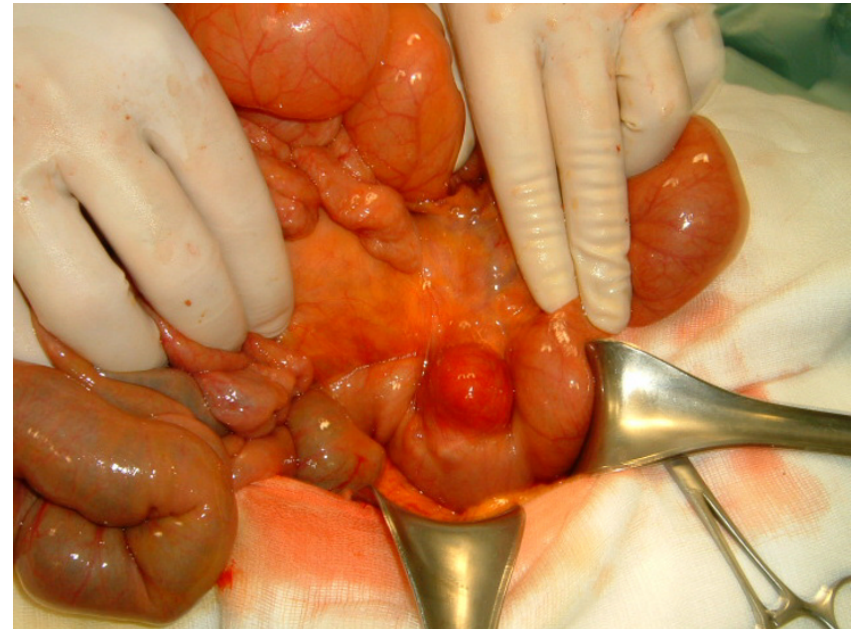

\section{Figure I}

Operative view: esophytic GIST of the fourth duodenal portion.

on the site and the size of the tumour and on the surrounding organs invasion. Total tumour resection is the standard of cure for GISTs. Nodes dissection is not recommended, because GISTs rarely metastasize to lymph nodes [22]. In eligible patients, total resection of a duodenal GIST can be achieved by a simple excision procedure, that is effective in controlling the bleeding and in achieving cure. Children may benefit of advantages from lesser demolitive duodenal surgery. Treatment with imatinib, an inhibitor of receptor tyrosine kinases (RTKs), may be offered to pediatric patients with advanced GIST disease,

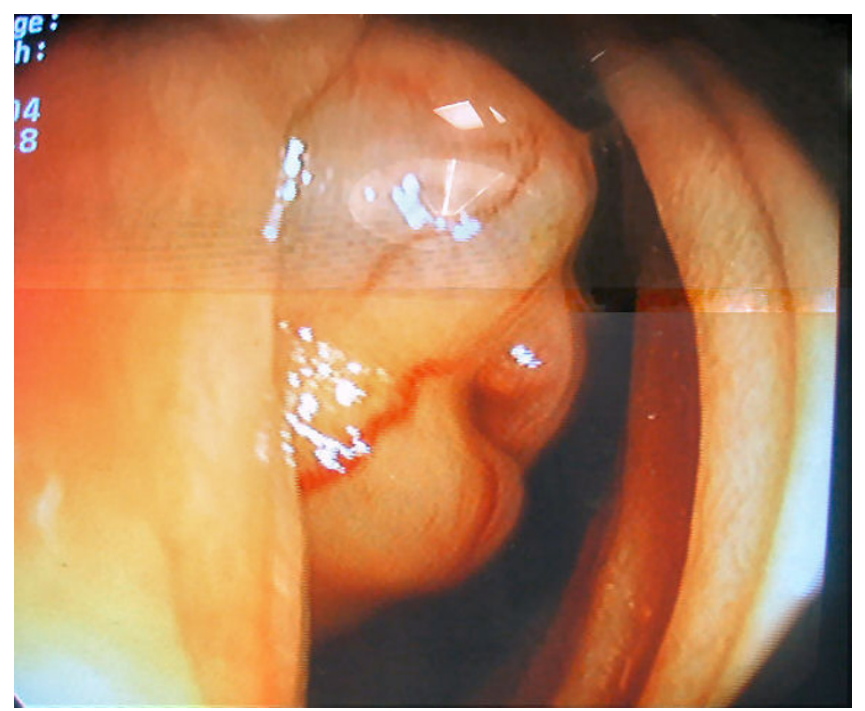

\section{Figure 2}

Intra-operative push-endoscopy: GIST protusion into the duodenal lumen with mucosa ulcerated.

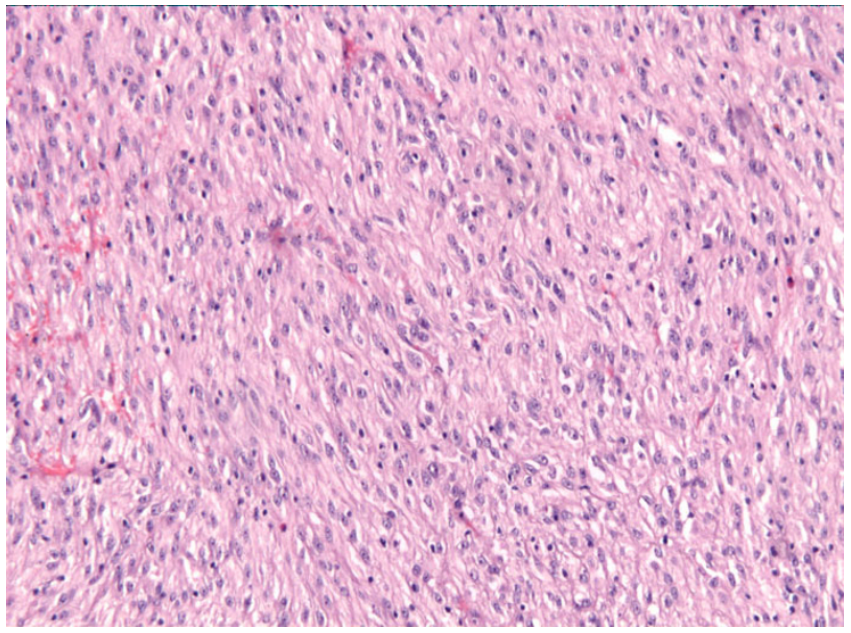

Figure 3

Microscopic appearance of the duodenal GIST demonstrating epithelioid and spindle cells (H\&E; magnification, $\times 10$ ).

not radically amenable by surgery. Several papers have reported a correlation between the nature of molecular alterations of KIT and PDGFR $\alpha$ and response to imatinib treatment [23-25]. In adults most GISTs are caused by mutations in the KIT or PDGFR $\alpha$ receptor tyrosine kinase genes and this make them amenable to therapy with imatinib. Thus, adult patients with unresectable or recurrent GIST have a better prognosis because the disease usually responds to therapy. In children genes mutations have been described in the rare cases of familial GISTs, but they do occur very rarely in sporadic GISTs $[11,12,26]$. Because most pediatric GISTs have KIT/PDGFR $\alpha$ wildtype pat-

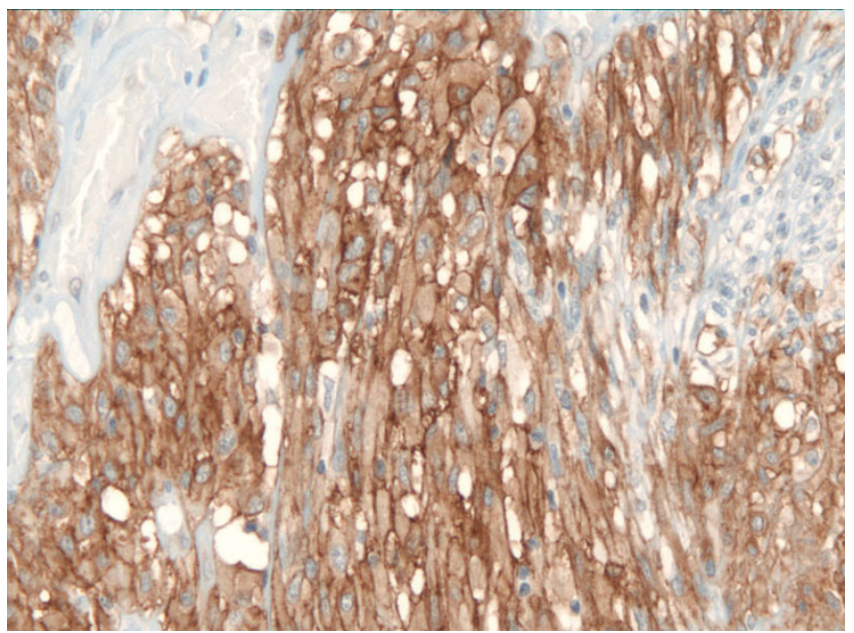

\section{Figure 4}

GIST cells stained positive for CDII7(c-KIT) (magnification, $\times 20)$. 
terns, these patients are expected to respond to imatinib treatment less well than adults do.

Complete surgical resection of GISTs seems however more likely in pediatric rather than in adult patients. In a paper presenting a series of pediatric patients with GIST and collecting data from literature, the rate of complete surgical resection was $80 \%$ (18 out 23 patients) and more than $90 \%$ of these patients survived with no evidence of recurrence [9]. In adults, complete surgical resection of GISTs has been reported in $40 \%$ of cases [27]. Moreover the recurrence of GISTs in adults ranges from 40 to $80 \%$ despite complete surgical resection of the primary tumor $[22,27]$. These data suggest a more benign course for pediatric GISTs respect to adult cases.

According to the risk assessment criteria [2], the GIST of the presented case fell in to the low-risk of aggressive behaviour category (tumour size $<5 \mathrm{~cm}$ and mitotic counts $<5$ mitotic figures per $50 \mathrm{HPF}$ ) and no chemotherapy after surgery was offered. Miettinen \& Coll. [4] in a review of 156 duodenal GIST including adult and pediatric patients, found that $86 \%$ of those with a tumour $>5$ cm with > 5 mitoses per 50 HPF died of disease, whereas no recurrence or metastases were seen in patients with tumour $<2 \mathrm{~cm}$ with $<5$ mitoses/50 HPF. However, they occasionally observed the development of metastases even if the mitotic activity was $<5 / 50 \mathrm{HPF}$ and the tumour size was $<5 \mathrm{~cm}$. Thus, in young patients, even for the lowaggressive category of totally resected duodenal GISTs, the long-term outcome remains unpredictable. A long-term follow-up study is strongly advisable.

\section{Competing interests}

The author(s) declare that they have no competing interests.

\section{Authors' contributions}

MC conceived of the study and participated in its design and coordination

\section{CG conceived of the study and participated in its design}

PL participated in the design of the study and drafted the manuscript

GZ participated in the design of the study and helped in drafting the manuscript

MS conceived of the study and participated in its coordination.

All the Authors read and approved the final manuscript.

\section{Acknowledgements}

Written consent was obtained from the parents of the patient for publication of the patient's details.

\section{References}

I. Kindblom LG, Remotti HE, Aldenborg F, Meis-Kindblom JM: Gastrointestinal pacemaker cell tumor (GIPACT): gastrointestinal stromal tumors show phenotypic characteristics of the interstitial cells of Cajal. Am J Pathol I998, I 52:1259-1269.

2. Fletcher CD, Berman JJ, Corless C, Gorstein F, Lasota J, Longley BG, Miettinen M, O'Leary TJ, Remotti H, Rubin BP, Smookler B, Sobin LH, Weiss SW: Diagnosis of gastrointestinal stromal tumors: A consensus approach. Hum Pathol 2002, 33:459-465.

3. Miettinen M, Sobin LH, Lasota J: Gastrointestinal stromal tumprs of the stomach: a clinicopathologic, immunohistochemical, and molecular genetic study of $\mathbf{1 7 6 5}$ cases with long-term follow-up. Am J Surg Pathol 2005, 29:52-68.

4. Miettinen M, Kopczynski J, Makhlouf HR, Sarlomo-Rikala M, Gyorffy $H$, Burke A, Sobin LH, Lasota J: Gastrointestinal stromal tumors, intramural leiomyomas, and leiomyosarcomas in the duodenum: a clinicopathologic, immunohistochemical, and molecular genetic study of $\mathbf{1 6 7}$ cases. Am J Surg Pathol 2003, 27:625-64l.

5. Miettinen M, Makhlouf H, Sobin LH, Lasota J: Gastrointestinal stromal tumors of the jejunum and ileum: a clinicopathologic, immunohistochemical, and molecular genetic study of 906 cases before imatinib with long-term follow-up. Am J Surg Pathol 2006, 30:477-489.

6. Tran T, Davila JA, El-Serag HB: The epidemiology of malignant gastrointestinal stromal tumors: an analysis of 1,458 cases from I 992 to 2000. Am J Gastroenterol 2005, I 00: I62-168.

7. Beghini A, Tibiletti MG, Roversi G, Chiaravalli AM, Serio G, Capella $C$, Larizza L: Germline mutation in the juxtamembrane domain of the kit gene in a family with gastrointestinal stromal tumors and urticaria pigmentosa. Cancer 200I, 92:657-662.

8. Chompret A, Kannengiesser C, Barrois M, Terrier P, Dahan P, Tursz $T$, Lenoir GM, Bressac-De Paillerets B: PDGFRA germline mutation in a family with multiple cases of gastrointestinal stromal tumor. Gastroenterology 2004, I 26:318-32I.

9. Cypriano MS, Jenkins JJ, Pappo AS, Rao BN, Daw NC: Pediatric gastrointestinal stromal tumors and leiomyosarcoma. Cancer 2004, I 0 I:39-50.

10. Hayashi Y, Okazaki T, Yamataka A, Yanai T, Yamashiro Y, Tsurumaru M, Kajiyama $Y$, Miyano T: Gastrointestinal stromal tumor in a child and review of the literature. Pediatr Surg Int 2005, 21:914-917.

II. Prakash S, Sarran L, Socci N, DeMatteo RP, Eisenstat J, Greco AM, Maki RG, Wexler RH, LaQuaglia MP, Besmer P, Antonescu CR: Gastrointestinal stromal tumors in children and young adults: a clinicopathologic, molecular, and genomic study of I 5 cases and review of the literature. J Pediatr Hematol Oncol 2005, 27:179-187.

12. Price VE, Zielenska M, Chilton-MacNeill S, Smith CR, Pappo AS: Clinical and molecular characteristics of pediatric gastrointestinal stromal tumors (GISTs). Pediatr Blood Cancer 2005, 45:20-24.

13. Towu E, Stanton M: Gastrointestinal stromal tumor presenting with severe bleeding: a review of the molecular biology. Pediatr Surg Int 2006, 22:462-464.

14. Hughes JA, Cook JV, Said A, Chong SK, Towu E, Reidy J: Gastrointestinal stromal tumour of the duodenum in a 7-year-old boy. Pediatr Radiol 2004, 34: I024-1027.

15. Hellies R, Sulis R, Puliga A, Pala M, Pietrangeli M: GIST: surgical treatment of 34 cases. Tumori 2003, 89:133-134.

16. D'Amato A, Brini A, Montesani C, Pronio A, Chessa A, Manzi F, Ribotta G: Gastrointestinal stromal tumors: a series of 23 surgically treated cases. Ann Ital Chir 2001, 72:175-180.

17. Goh BK, Chow PK, Ong HS, Wong WK: Gastrointestinal stromal tumor involving the second and third portion of the duodenum: treatment by partial duodenectomy and Roux-en-Y duodenojejunostomy. J Surg Oncol 2005, 91:273-275.

18. Kurihara N, Kikuchi T, Tanabe M, Kumamoto Y, Tsuyuki A, Fujishiro Y, Otani Y, Kubota T, Kumai K, Kitajima M: Partial resection of the second portion of the duodenum for gastrointestinal stromal 
tumor after effective transarterial embolization. Int J Clin Oncol 2005, 10:433-437.

19. Wellmann K, Gohla G, Wenk H: Malignant gastrointestinal stromal tumor (GIST) of papilla vateri: a rare tumor entity. Chirurg 2004, 75:196-99.

20. Sakakima Y, Inoue S, Fujii T, Hatsuno T, Takeda S, Kaneko T, Nagasaka T, Nakao A: Emergency pylorus-preserving pancreatodudodenenctomy followed by second stage pancreatojejunostomy for a gastrointestinal tumor of the duodenum with an intratumoral gas figure: report of a case. Surg Today 2004, 34:70I-705.

21. Akkus MA, Kismet K, Adibelli MA, Pulat H: Case report: duodenal stromal tumor. Acta Gastroenterol Belg 2005, 68(I):95-7.

22. Joensuu $H$, Fletcher $C D$, Dimitrijevic $S$, Siberman $S$, Roberts $P$, Demetri G: Management of malignant gastrointestinal stromal tumours. Lancet Oncol 2002, 3:655-664.

23. Heinrich MC, Corless CL, Demetri GD, Blanke CD, von Meheren M, Joensuu H, McGreevey LS, Chen C], Van den Abbeele AD, Druker BJ, Kiese B, Eisenberg B, Roberts PJ, Singer S, Fletcher CD, Silberman S, Dimitrijevic S, Fletcher JA: Kinase mutations and imatinib response in patients with metastatic gastrointestinal stromal tumor. J Clin Oncol 2003, 21:4342-4349.

24. Debiec-Rychter M, Dumez H, Judson I, Wesag B, Verweii J, Brown M, Dimitrijevic S, Sciot R, Stul M, Vranck H, Scurr M, Hgemeijer A, van Glabbeke M, van Oosterom AT: EORTIC Sof Tissue and Bone Sarcoma Group. Use of c-KIT/PDGFRA mutational analysis to predict the clinical response to imatinib in patients with advanced gastrointestinal stromal tumors entered on phase I and II studies of the EORTIC Soft Tissue and Bone Sarcoma Group. Eur J Cancer 2004, 40:689-695.

25. Corless CL, Fletcher JA, Heinrich MC: Biology of gastrointestinal stromal tumors. J Clin Oncol 2004, 22:3813-3825.

26. Miettinen M, Lasota J, Sobin LH: Gastrointestinal stromal tumors of the stomach in children and young adults: a clinicopathologic, immunohistochemical, and molecular genetic study of 44 cases with long-term follow-up and review of the literature. Am J Surg Pathol 2005, 29: | 373-|38|.

27. DeMatteo RP, Lewis JJ, Leung D, Mudan SS, Woodruff JM, Brennan MF: Two hundred gastrointestinal stromal tumors: recurrence patterns and prognostic factors for survival. Ann Surg 2000, $231: 51-58$.

\section{Pre-publication history}

The pre-publication history for this paper can be accessed here:

http://www.biomedcentral.com/1471-2407/7/79/prepub
Publish with Bio Med Central and every scientist can read your work free of charge

"BioMed Central will be the most significant development for disseminating the results of biomedical research in our lifetime. "

Sir Paul Nurse, Cancer Research UK

Your research papers will be:

- available free of charge to the entire biomedical community

- peer reviewed and published immediately upon acceptance

- cited in PubMed and archived on PubMed Central

- yours - you keep the copyright
BioMedcentral 